\title{
Akne Skarları Tedavisinde Otolog Kültüre Fibroblast Enjeksiyonu
}

\author{
Injection of Autologous Cultured Fibroblast for the \\ Treatment of Acne Scars
}

\section{Osman Köse, İbrahim Özmen*, Yıldıray Yeniay}

Gülhane Askeri Tıp Akademisi, Deri ve Zührevi Hastalıklar Anabilim Dalı, Ankara, Türkiye

*Çorlu Asker Hastanesi, Deri ve Zührevi Hastalıklar Bölümü, Çorlu, Tekirdağ, Türkiye

\section{Özet}

Amaç: Yüzde olușan akne skarları bugün hala önemli bir kozmetik problemdir. Biz bu çalıșmada intradermal otolog fibroblast injeksiyonunun akne skarlarındaki tedavi etkinliği ve güvenirliliğini saptamayı amaçladık.

Gereç ve Yöntemler: Bu çalıșma açık, prospektif, Faz 3 așamalı bir pilot çalıșmadır. Yașları 21-35 arasında değișen akne skarı olan 6 hasta (4 Erkek, 2 kadın) bu çalıșmaya alınmıștır. Otolog fibroblastlar iki doz halinde 20 milyon/ml olarak 2 hafta arayla uygulanmıștır. Hastalar ilk injeksiyondan sonraki 2, 4, 6, ve 12. aylarda değerlendirilmișlerdir. Subjektif değișme skorları her vizitte hasta ve doktor tarafından değerlendirilerek kaydedilmiștir.

Bulgular: Altı aylık takip sonunda 2 hastada \%50'nin üzerinde düzelme görülürken, 12 aylık takip sonucunda 6 hastanın 5 tanesinde \%50-75 arasında düzelme sağlanmıștır. En iyi sonuçlar 12. ayda alınmıștır. Tedavi sırasında ciddi yan etki saptanmamıștır. Intradermal otolog fibroblast injeksiyonu, bu küçük serili pilot çalıșmada etkili ve güvenilir bulunmuștur. (Türkderm 2012; 46: 90-3)

Anahtar Kelimeler: Fibroblast, akne, hücre kültürü

\section{Summary}

Background and Design: Acne scars on the face are still an important cosmetic problem. In this study, we aimed to determine the efficacy and safety of intradermal injections of autologous fibroblasts for the treatment of acne scars.

Materials and Methods: This was an open, prospective, phase 3, pilot study. Six adults with acne scars (4 male, 2 female; age range: 21 35 years) were included in this study. Autologous cultured fibroblasts $(20 \mathrm{million} / \mathrm{ml})$ were given as two doses administered with two weeks interval. Efficacy evaluation was performed 2, 4, 6, and 12 months after the first injections. Subjective improvement scores were noted by patient and clinicians at every follow-up visit.

Results: An improvement in acne scars of more than 50\% was observed in two of the 6 at 6 months while five of the 6 patients and clinicians also noted $50 \%$ to $75 \%$ improvement with the treatment at 12 months. The best results were obtained at 12 months. No serious side effects were detected.

Conclusion: In this pilot study, intradermal injections of autologous fibroblast were found to be effective and safe for acne scars. (Turkderm 2012; 46: 90-3)

Key Words: Fibroblast, acne, cell culture

\section{Giriş}

Akne adölesan dönem dışında da görülebildiği için, hastaların sosyal anlamda iletişimlerini bozan ve onların kendilerine güvenini sarsan ciddi skarlara yol açabilen bir hastalıktır. Akne skarları için önerilen hyalunorik asit içeren klasik dolgu maddeleri, uzun süreli tedavi yazılması sağlamamakta bunun yanında cerrahi bir yöntem olan dermabrazyon tedavisi de her hasta için uygun olmamaktadır. Otolog kültüre fibroblast (OKF) tedavileri kronik venöz ülserler, diabetik ayak ülseri, bası ülserleri yanıklar ve genodermatozlarda giderek artan bir sıklıkta kullanılmaktadır1,2. Dermatoloji dışında periodontolojik jinjival

Yazışma Adresi/Address for Correspondence: Dr. Osman Köse, Gülhane Askeri Tıp Akademisi, Deri ve Zührevi Hastalıklar Anabilim Dalı, Ankara, Türkiye Tel.: +90 3123044453 E-posta: okose@gata.edu.tr Geliş Tarihi/Received: 02.08.2011 Kabul Tarihi/Accepted: 15.09.2011

Türkderm-Deri Hastalıkları ve Frengi Arșivi Dergisi, Galenos Yayınevi tarafından basılmıștır. Turkderm-Archives of the Turkish Dermatology and Venerology, published by Galenos Publishing. 
hastalıklarda da OKF yaygın şekilde kullanılmaktadır³. Bu araştırmada ise pilot bir çalışma olarak otolog kültüre fibroblast injeksiyonunun akne skarlarındaki etkinliği ve güvenilirliği için Faz 3 klinik çalışma olarak planlanmıştır. Bu projeye Türk Dermatoloji Derneği tarafından "Araştırma Desteği " (2008) verilmiştir.

\section{Gereç ve Yöntem}

\section{Hasta seçimi}

Çalışmamıza 21-35 yaş arasında dermatolojik muayene sonunda aktif akne lezyonu saptanmayan ve geçirilmiş akneye bağlı belirgin skarları bulunan hastalar alınmıştır. Çalışmaya alınan hastalarda son bir yıl içinde topikal veya sistemik herhangi bir ilaç kullanmamış olmaları ve ayrıca skar tedavisi için herhangi bir tıbbı ve kozmetik işlem (peeling, mezolifting) veya dermabrazyon yaptırmamış olmaları şartı aranmıştır. Ayrıca hastaların hipertrofik skar veya keloid oluşumuna eğilimli bir deri yapılarının olmamasına da dikkat edilmiştir. Her olgu çalışma öncesinde akne skar sayısı, yerleşimi ve boyutu açısından değerlendirilmiştir ve kayıt edilmiştir. Değerlendirme akne skarı şiddeti skoruna göre 7 derecede sınıflanmıştır. Bu çalışmada Weiss ve ark. ları tarafından geliştirilen akne skar skorlama sistemi kullanı Imıştır. Tüm hastalara 2 kez 20 milyon/ml olacak şekilde her injeksiyonda 2 $\mathrm{ml}$ otolog fibroblast injeksiyonu yapılmıştır. Tedaviden sonraki 2., 4., 6. ve 12. aylarda tedavi sonuçları ve yan etkiler hasta ve hekim tarafından değerlendirilmiştir. Tedaviyi kabul eden ve onam formunu

\section{Ay Tedavi Değerlendirmesi}
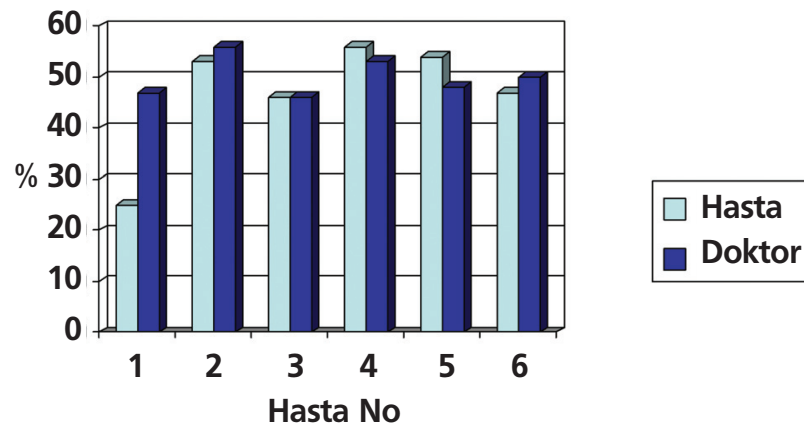

Şekil 1. 6. ay tedavi değerlendirmeleri

\section{Ay Tedavi Değerlendirmesi}

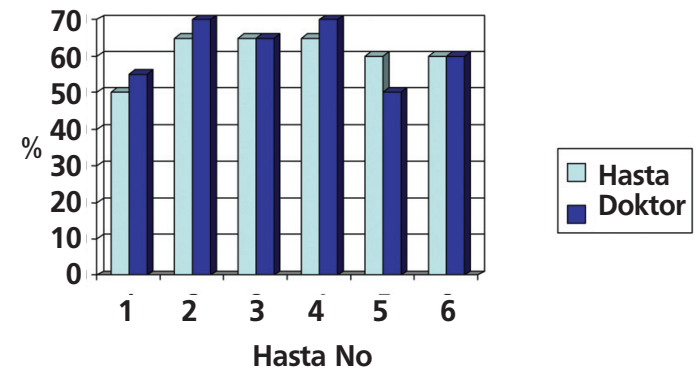

Şekil 2. 12. ay tedavi değerlendirmeleri imzalayan hastalar tedaviye alınmıştır. Tedavi öncesinde hastalara, diğer kültür ortamlarını ve laboratuvarları kontamine etmemek için HBs Ag, Anti HCV, Anti HBC, Ig M, HIV Tip 1 ve HIV Tip 2 Ag, VDRL ve TPHA testleri yapılmıştır. Çalışmamız Faz 3 klinik çalışma olarak değerlendirilerek yerel etik kurul izni alınarak yapılmıştır (2009/127).

\section{Doku Örneği Alınması ve Hücre Kültürü}

Seçilen hastaların pubik bölgesinden alınan $6 \mathrm{~mm}^{\prime}$ lik punch biopsi örnekleri uygun medyalarla soğuk zincir sevkiyle Trabzon Karadeniz Teknik Üniversitesinde bulunan ATi Laboratuvarlarına gönderilmiştir. Buradaki işlemleri takiben yaklaşık olarak 4-6 haftalık bir süre içinde yine uygun soğuk zincir sevkiyle GATA Dermatoloji $A D^{\prime}$ na ulaştırılmıştır. ATi laboratuvarları ülkemizde insan hücre kültür uygulamalarının yapılabildiği Sağlık Bakanlığından lisanslı tek laboratuvardır. Hastaların skarlı yüz bölgelerine Emla krem ile yapılan bölgesel anestezi uygulamasından 30 dakika sonra 1. fibroblast injeksiyonu yapılmış ve aynı uygulama 2 hafta sonra tekrarlanmıştır. Her injeksiyonda, fibroblastlar 20 milyon hücre/ml olacak şekilde toplam $3 \mathrm{ml}$. intradermal olarak uygulanmıştır. Tedavi sonrası bu bölgeye ödemi ve ağrıyı azaltmak amacıyla buz kompresi yapılmıştır. Hastalar tedaviden sonraki 2., 4., 6. ve 12. aylarda muayene edilerek fotoğrafları çekilmiş ve tedavi değerlendirilmiştir. Tedavi etkinliği hasta ve hekim (Dr. OK) tarafından 0: Değişiklik yok, 1: Minimal değişiklik (\%0-25) 2: Orta derecede değişiklik (\%26-50), 3: İyi derecede değişiklik (\%51-75) 4: Çok İyi derecede değişiklik (\%76-100) olarak değerlendirilmiştir.

\section{Bulgular}

Çalışmaya projenin toplam maliyeti çerçevesinde 6 hasta alınabilmiştir. Hastaların yaş ortalamaları 20-35 (SD $\pm 10,75)$ olup 4 erkek, 2 kadın hastadan oluşmaktadır. Hastaların demografik bilgileri Tablo 1'de gösterilmiş̧ir. Altıncı ay ve 12. ay hasta ve hekim tedavi sonuçları Şekil 1 ve Şekil-2'de gösterilmiştir. Altıncı ay sonuçlarının hastalar tarafından değerlendirilmelerinde yalnızca bir hasta minimal değişiklik ifade ederken 2 hasta orta derecede değişiklik, 3 hasta ise iyi derecede değişiklik olduğunu gözlemiştir. On ikinci ay hasta değerlendirmesinde ise bir hasta orta derecede, 5 hasta iyi derecede değişiklik ifade etmiştir. Hekim değerlendirmelerinde ise 6 . ayda 4 hastada orta derecede düzelme, 2 hastada iyi derecede düzelme saptanırken 12. ayda ise 2 hastada orta derecede düzelme ve 4 hastada iyi derecede düzelme belirlenmiştir. Bu sonuçlara göre tüm hastalarda 12. ay sonuçları hem hasta hem de hekim tarafından daha iyi bulunmuştur. Tedavi sonunda hastaların ortalama tedavi yüzdeleri 6. ayda \%51-65, 12. ayda $\% 60-78$ arasındadır. Tedavi edilen bir hastamıza ait tedavi öncesi ve OKF tedavisi sonundaki fotoğraflar Şekil $3 a / b$ ve Şekil $4 a / b$ 'de gösterilmiştir. Klinik

Tablo 1. Hastaların demografik bilgileri

\begin{tabular}{|c|c|c|c|}
\hline No & Yaş/Cins & $\begin{array}{c}\text { Skar derecelendirmesi } \\
\text { (Grade1-6) }\end{array}$ & $\begin{array}{c}\text { Skar süresi } \\
\text { tedavi öncesi anksiyete }\end{array}$ \\
\hline 1 & $31 / \mathrm{E}$ & Grade 5 & $10 \mathrm{yll}$ \\
\hline 2 & $21 / \mathrm{E}$ & Grade 4 & $5 \mathrm{yll}$ \\
\hline 3 & $21 / \mathrm{E}$ & Grade 3 & $3 \mathrm{yll}$ \\
\hline 4 & $35 / \mathrm{K}$ & Grade 4 & $15 \mathrm{yll}$ \\
\hline 5 & $25 / \mathrm{K}$ & Grade 3 & $10 \mathrm{yll}$ \\
\hline 6 & $21 / \mathrm{E}$ & Grade 3 & $5 \mathrm{yll}$ \\
\hline
\end{tabular}



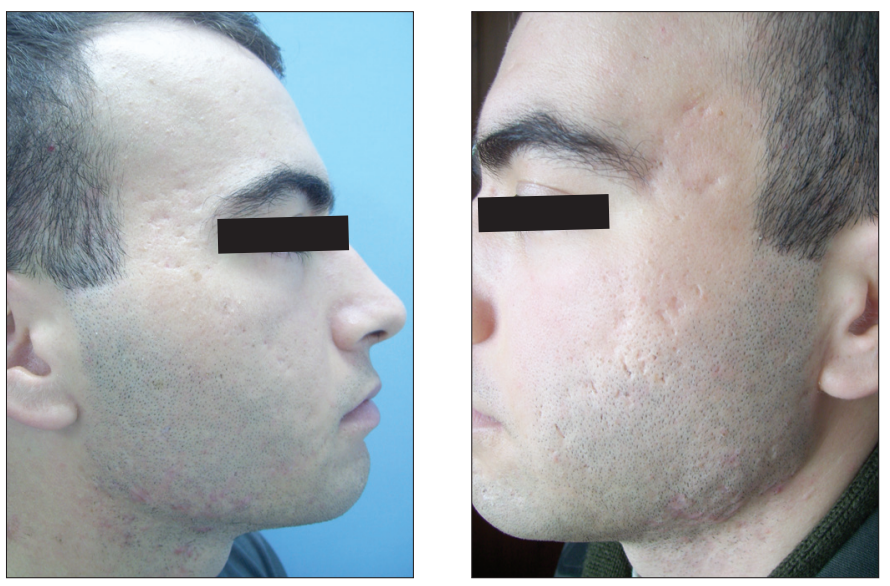

Şekil 3a-b. Tedavi öncesi akne skarları
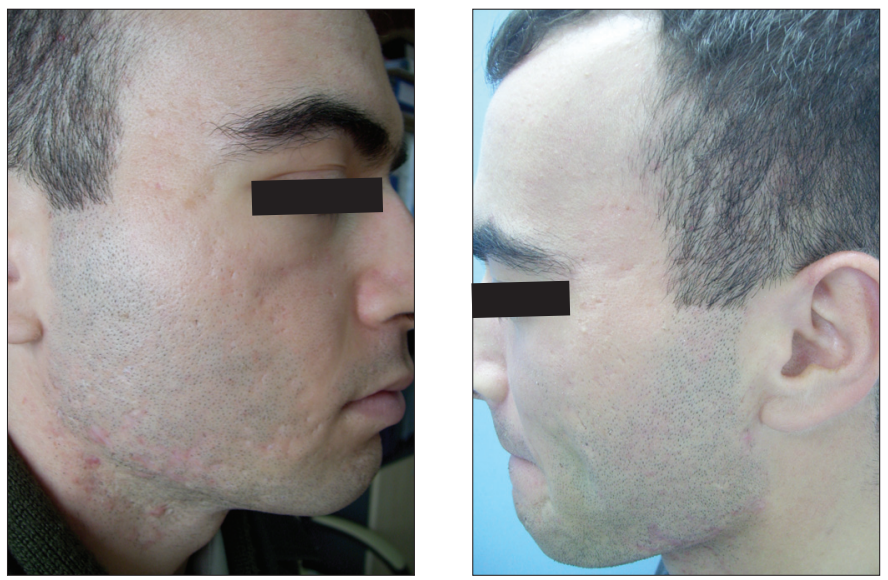

Şekil 4a-b. 12. ay otolog fibroblast tedavi sonu

gözlemlerimiz yeni oluşan akne skarlarının tedaviye daha iyi yanıt verdiğidir. Tedavi sırasında fibroblast injeksiyonu ile hafif ödem ve eritem oluşmuştur. Bunun dışında tedavi sırasında ve sonrasında hasta ve hekim tarafından bildirilen bir yan etki olmamıştır.

\section{Tartışma}

Dermatokozmetolojide akne skarları için dolgu maddeleri uzun süredir kullanılmaktadır4,5. Bu amaçla kullanılan ürünler sığır kollajeni ya da hyalunorik asit içeren ürünlerdir. Ancak bu tedavilerde bir süre sonra ürün yıkımına bağlı uygulama tekrarları gerekmektedir. Oluşabilecek yan etkiler nedeniyle bu tür ürünler akne skarlarında daha nadir kullanılmaktadır.

Dermal fibroblastların deride birçok rolü vardır. Ekstrasellüler matriks sentezlenmesi ve depolanması, kemotaktik, mitojenik ve modulatör sitokinlerin proliferasyonu ve migrasyonu yanında fibroblastlar otokrin ve parakin etkileşimi de sağlar1,6-8. Fibroblast, dermisin ana hücresi olup kollajen kalınlığında artış oluşturmaktadır. Otolog kültüre fibroblastlar kozmetik anlamda ilk kez 1995 yılında kullanılmışlardır. OKF dinamik protein yenileyici sistem olarak bilinmektedir6,8. İnjeksiyon yapıldıktan kısa süre sonra otolog fibroblastlar özellikle yeni Tip III kollajen sentezlemektedirler. Bu etki hastaların büyük bölümünde 3 yıl gibi bir süre içinde $\% 70$ oranında devam edebilmektedir7. Akne skarlarında ilk olarak, OKF ile 1250 hastaya 4800 injeksiyon yapılarak gerçekleştirilen geniş bir çalışmada akne skarı ve nazolabial kırışıklık tedavi edilmiştir9. Bu çalışma sonunda toplam hasta memnuniyeti ilk yıl \%92 iken 3.-4. yıllarda \%70 oranında saptanmıştır. Son yıllarda yapılan bir araştırmada ise OKF ile tedavi edilen hastaların skarlarında 9. ve 12. aylarda \%75 ve \%81 oranında düzelme saptanmış ve bunun en az 12 ay devam ettiği belirlenmiştir ${ }^{10}$. Watson ve ark'ları akne skarı bulunan 10 hastada OKF tedavisi ile 6. ay sonunda \%60-100 arasında gelişme saptamışlar ve skar yüzeyinde \%10-85 arasında küçülme belirlemişlerdir ${ }^{11}$. Akne skarları içinde ice-pick olarak isimlendirilen skar tipleri bu tedaviden fayda görmemektedir. OKF tedavisi yapılan hastalardan alınan deri biopsilerinde dermisin kalınlığında ve fibroblast hacminde artışın yanında inflamasyonun gözlenmediği histopatolojik olarak saptanmıştır6-8. Bu çalışmalarda bildirilen en ciddi yan etki, Boss ve ark.'larının 4800 injeksiyonun 11 'inde karşılaştıkları 10 gün kadar süren kızarıklık ve indürasyondur ${ }^{9}$. OKF tedavisinin daha etkili ve uzun süreli olması için bazı materyallerin (hyalunorik asit) eklenmesinin yararlı olacağı düşünülmüş ve bir hayvan deneyinde OKF yalnız ve OKF/ hyalunorik asit kombinasyonu ratların sırt derisine injekte edilerek sonuçlar morfometrik ve morfolojik olarak değerlendirilmiştir ${ }^{12}$. Bu araştırma sonucunda OKF ile hyalunarik asit kombinasyonunun daha uzun süreli etkinlik gösterdiği saptanmıştır. Dermatolojide OKF dermatokozmetolojik alanlar dışında iradiye olmuş deride ve yanık yaralarının iyileştirilmesi ve bunun dışında da layşmanyada oluşan skarların tedavisinde de uygulanmıştır13-15. Tüm bu çalışmalarda da otolog fibroblast tedavileri ile çok iyi sonuçlar alındığı belirtilmiştir.

OKF tedavisinin avantaj ve dezavantajları bulunmaktadır. Bu tedavinin en önemli avantajı, otolog yağ trasferine göre daha az bir doku örneği (6 mm.lik punch biopsi) gerektirmesi, fibroblastların kollajen üreterek skar tedavisine katkıda bulunmalarına karşın otolog yağ transferinin dolgu maddesi implantasyonu gibi işlev görmesidir. OKF tedavisinin bir diğer avantajı ise belli bir yaş aralığında alınan fibroblastların $-80{ }^{\circ} \mathrm{C}$ de saklanarak istenilen zamanda tekrar kullanılabilmesidir. Böylece hücre yaşlanmasının önüne geçmek mümkün olabilmektedir. Bu tedavi yönteminin en önemli dezavantajı ise yüksek sayılabilecek tedavi maliyetidir. Bununla beraber 2-3 yıllık süre içinde uygulanacak olan dolgu madde tedavilerinin toplam maliyetinin OKF tedavi maliyetlerine yakın olduğu söylenebilir. Bu çalışma ülkemizde yapılan ilk klinik uygulamalardan olup zaman içinde tedavi maliyetinin azaltılabileceği düşünülmektedir. Bu durum ise yöntemin daha sık kullanılmasına yardımcı olabilecektir.

Bu çalışmanın en önemli kısıtıııklarından biri hasta sayısının azlığıdır. Her hasta için maliyetin 2.500 TL civarında olması hasta sayısını kısıtlamıştır.

Sonuç olarak ülkemizde ilk kez yapılan bu çalışmada OKF injeksiyonunun akne skarlarında etkili ve güvenilir bir tedavi yöntemi olduğu söylenebilir. Yapılan çalışmalarda 3 seans fibroblast uygulaması ile daha yüksek başarı oranlarının elde edildiği bildirilmiş̧ir8,11. Bu nedenle yöntemin 20 milyon/ml dozuyla 3 seans halinde uygulanması ile iyi sonuçlar alınabileceği düşünülmektedir. Ayrıca tedavi maliyetlerinin düşürülmesi ile daha çok hastanın bu yöntemden faydalanması söz konusu olacaktır. OKF injeksiyonu dermal yoğunluğu artırıcı katkı maddeleri ile beraber uygulanması durumunda daha uzun süre kalıcılık gösterecek ve akne skarları dışında nazolabial alan kırışıklıklarında ve skarla sonuçlanan birçok deri hastalığında da önemli bir alternatif tedavi olarak yer alacaktır. 


\section{Kaynaklar}

1. Wong $\mathrm{T}, \mathrm{Mc}$ Grath JA, Navsaria $\mathrm{H}$ : The role of fibroblasts in tissue engineering and regeneration. Br J Dermatol 2007;156:1149-55.

2. Bello $Y M$, Falabella AF, Eaglstein WH: Tissue-engineered skin. Current status in wound healing. Am J Clin Dermatol 2001;2:305-13.

3. Mc Guire MK, Scheyer ET: A randomized, double-blind, placebocontrolled study to determine the safety and efficacy of cultured and expanded autologous fibroblast injections for the treatment of interdental papillary insufficiency associated with the papilla priming procedure. J Periodontol 2007;78:4-17.

4. DeVore DP, Hughes E, Scott JB: Effectiveness of injectable filler materials for smoothing wrinkle lines and depressed scars. Med Prog Technol 1994;20:243-50.

5. Sclafani AP, Romo T 3rd, Parker A et al: Autologous collagen dispersion (Autologen) as a dermal filler: clinical observations and histologic findings. Arch Facial Plast Surg 2000;2:48-52.

6. Nolte SV, Xu W, Rennakampff HO, Rodemann HP: Diversity of fibroblastsa review on implications for skin tissue engineering. Cells Tissue Organs 2008; 187:165-76.

7. Zhao $Y$, Wang J, Yan $X$, Li D. Xu J: Preliminary survival studies on autologous cultured skin fibroblasts transplantation by injection. Cell Transplant 2008;17:755-83.
8. Boss WK, Usal H, Fodor PB, Chernoff G: Autologous cultured fibroblasts; a protein repair system. Ann Plast Surg 2000;44:536-42.

9. Boss WK, Usal H, Chernoff $G$ et al: Autologous cultured fibroblast as cellular therapy in plastic surgery. Clin Plast Surg 2000;27:613-26.

10. Weiss RA, Weiss MA, Beasley KL, Munavalli G: Autologous cultured fibroblast injection for facial contour deformities: a prospective, placebocontrolled, Phase III clinical trial. Dermatol Surg 2007;33:263-8.

11. Watson D, Keller GS, Lacombe $V$ et al: Autologous fibroblasts for treatment of facial rhytids and dermal depressions. A pilot study. Arch Facial Plast Surg 1999;1:165-70.

12. Solakoğlu S, Tiryaki T, Çiloğlu SE: The effect of cultured autologous fibroblast on longevity of cross-linked hyalunaric acid uses as a filler. Asthetic Surg J 2008;28:412-6.

13. Ferguson PC, Boynton EL, Wunder JS et al: Intradermal injection of autologous dermal fibroblasts improves wound healing in irradiated skin. J Surg Res 1999;85:331-8.

14. Karchilaki I, Topakas G, Castana O et al: The use of cultured autologous fibroblasts in burn wounds healing process. Burns 2007;33:791-2. Epub 2007 Feb 15.

15. Nilforoushzadeh MA, Esfahani MHN, Fesharaki MA et al: Treatment of atrophic cutaneous leishmaniasis scar using autologous fibroblasts and keratinocytes (a case report and literature review) J Res Med Sci 2010;15:125-6. 